\title{
Effect of zona pellucida removal on early development of in vitro produced bovine embryos ${ }^{\#}$
}

\author{
Efecto de la remoción de la zona pelúcida sobre el desarrollo temprano de \\ embriones bovinos producidos in vitro
}

\author{
AE Velásquez, JR Manríquez, FO Castro, LI Rodríguez-Alvarez* \\ Department of Animal Science, Faculty of Veterinary Sciences, Universidad de Concepción, Chillán, Chile.
}

\begin{abstract}
SUMMARY
During early embryo development the zona pellucida acts as a barrier against polyspermia and guarantees communication between blastomeres before and during compaction. However, the development of new technologies of embryo production such as "Handmade Cloning" demands removal of this membrane. The aim of this study was to determine the effect of zona pellucida removal on in vitro bovine embryo development. First, the consequences of zona pellucida removal was assessed by comparing the percentage of first cleavage, percentage of blastocysts and cell number among zona-included and zona-free embryos; either through the removal of the zona pellucida immediately after IVF or parthenogenesis. Embryo development was also evaluated when zona pellucida was removed before parthenogenesis. In a second set of experiments, the gene expression levels of BAX, BCL2, CASP3, CDH1, OCT4 and SOX2 were evaluated in zona-free and zona-included IVF-derived embryos. No significant differences were found in the percentage of first cleavage, percentage of blastocyst and cell number on IVF-embryos cultured with or without zona. Parthenogenetic embryos followed the same general pattern even when the zona pellucida was eliminated before activation; however there was a significant increase in the rate of first cleavage when the zona pellucida was removed after activation but this did not impact upon further development. Furthermore, no significant differences in gene expression level were found between zona-free and zona-included IVF-embryos for the studied genes. We concluded that the lack of zona pellucida did not affect the early development when an appropriate system is used for embryo culture to ensure blastomeric contact and normal compaction.
\end{abstract}

Key words: parthenogenesis, zona-free, well of the well, gene expression.

Palabras clave: partenogénesis, zona pelúcida, embriones, bovinos.

\section{INTRODUCTION}

During in vivo embryo development the zona pellucida has clear functions, related with oocyte growth and protection before and after ovulation (Wassarman and Litscher 2008, Michelmann et al 2007), spermatozoa selection and avoiding polyspermy during fertilization (Austin and Braden 1956, Sun 2003, Bedford 2008). Also the zona pellucida ensures contact between blastomeres before and during compaction (Bronson and McLaren 1970, Suzuki et al 1995). This membrane also avoids premature embryo adhesion to the oviductal wall, chimera formation and also regulates embryo-maternal cross talk during early embryo development (Wolf et al 2003). However, some of these crucial functions are bypassed when embryos are produced in vitro. For instances, several advanced pregnancies have been reported after the transfer of human embryos produced by intracytoplasmic sperm injection (ICSI) of oocytes that have lost the zona pellucida as a consequence

Accepted: 11.10.2012.

\# This work was partially funded by Fondecyt grant $\mathrm{N}^{\circ} 11100082$ of the Ministry of Education of Chile and by grant $\mathrm{N}^{\circ} 209.153 .020-1.0$ of the University of Concepción, Chile.

* Av. Vicente Méndez 595, Chillán, Chile; 1lrodriguez@udec.cl of mechanical damage during oocytes retrieval (Stanger et al 2001).

On the other hand, the thickness and hardening of the zona pellucida impairs the hatching ability of in vitro produced embryos contributing to their relative low implantation rate (Cohen 1992). In humans, a correct hatching process occurs only in good-quality blastocysts, while poor-quality embryos would fail to initiate or complete hatching once they are transferred (Urman et al 2002). However, in a previous study, Fong et al (2001) demonstrated that the success of hatching in vitro does not correlate with blastocyst quality, indicating that is possible to rescue those embryos with hatching difficulties by removing the zona pellucida before embryo transfer.

Several studies have demonstrated that partial or complete removal of the zona pellucida in human blastocysts increases implantation rates, mainly in patients with poor fertility prognosis (Cohen 1990, 1992, Fong et al 1997, Urman et al 2002). There are several methods for zona removal including mechanical dissection, laser drilling, lysis by acidified Tyrode's solution and enzymatic digestion with pronase (Fong et al 1998, Jelinkova et al 2003, Ritchie et al 2005, Lagutina et al 2007, Rodriguez et al 2008). There is no evidence on the potential detrimental effect of zona removal for the inner-cell mass or trophoectoderm at blastocyst stage (Urman et al 2002). 
Hand made cloning is an easier and more affordable alternative method to produce cloned animals, which does not require expensive equipment such as micromanipulators, inverted microscope, pulling and beveling devices for microinstruments (Vajta et al 2001, Rodriguez et al 2008). However, this technique is based on a simple method for enucleation of the oocytes using a micro blade where the zona pellucida has to be removed to facilitate the enucleation procedure. Nevertheless, in this case the absence of zona pellucida has several advantages instead of being detrimental. The lack of zona enhances cell-oocyte fusion after an electrical pulse, this in turn increases the number of reconstructed embryos that can be cultured, reducing the working time and, as in human, it reduces the difficulties of implantation associated to embryo hatching (Rodriguez et al 2008).

The dilemma caused by the absence of the zona pellucida in embryo culture was solved by the use of well of the well (WOW) culture system (Vajta et al 2000, 2008). The rate of development to blastocysts as well as the efficiency of birth of healthy animals is not different when embryos were produced by HMC compared with the conventional procedure (Bhojwani et al 2005, Lagutina et al 2007). Currently, several groups are using HMC as the first alternative to generate cloned animals from different species. This preference is supported by the simplicity of the technique and the possibility for small laboratories to adopt it.

Despite the advantage of zona-free embryo production, very little is known about the effect of zona pellucida removal on early embryo development and quality. In mammals, during the first stages of embryo development and before the start of zygotic transcription, blastomeres are totipotent cells with the ability to differentiate into any cell type. Moreover, in mouse embryos, cell lineages are determined by signaling and induction through cell contacts that are established at 4-cell stage (Edwards and Beard 1997). In these cases, cell determination relies on cell interaction and on the gradient of signals from the surrounding cells.

When the zygote is cultured without zona pellucida, there is a risk for the blastomeres to lose their contact after several divisions provoking the induction of the mechanisms of cell death by apoptosis. This leads to a decrease of total cell number and blastocyst quality. Levy et al (2001) demonstrated that in human and mouse, the number of cells correlated negatively with the percentage of TUNEL-positive cells at the blastocyst stage, indicating a correlation between total cell number and embryo quality.

Acording to the above mentioned, it could be possible that zona pellucida removal could hamper normal embryo development due to a reduction of embryo quality. The goal of this work was to evaluate the effect of zona pellucida removal on early embryo development using as a model bovine embryos produced by IVF or parthenogenesis.

\section{MATERIAL AND METHODS}

\section{OOCYTE COLLECTION AND IN VITRO MATURATION (IVM)}

All reagents and media except otherwise stated were from the Sigma Chemical Co (St Louis, MO, USA). Oocyte collection and maturation was performed as described earlier (Rodriguez et al 2008). In brief, cumulus-oocyte complexes (COCs) were aspirated from medium-sized (3 to $8 \mathrm{~mm}$ diameter) follicles of bovine ovaries collected from a local slaughterhouse. The COCs were in vitro matured in TCM199 Earle's salts, supplemented with follicle stimulating hormone (FSH) and luteinizing hormone (LH) $(0.01 \mathrm{U} / \mathrm{ml}$ each $), 17 \beta$-oestradiol $(1 \mu \mathrm{g} / \mathrm{ml})$, epidermal growth factor (EGF; $10 \mathrm{ng} / \mathrm{ml}$ ) and $10 \%$ fetal bovine serum (FBS) at $39{ }^{\circ} \mathrm{C}$ in a $5 \% \mathrm{CO}_{2}$ in air atmosphere. Oocytes were matured for $24 \mathrm{~h}$ for IVF or parthenogenesis.

\section{IN VITRO EMBRYO PRODUCTION}

For IVF-derived embryos, matured oocytes were in vitro fertilized with thawed semen from a single bull of proven fertility. The motile fraction of the semen was obtained using a Percoll gradient (45\% Percoll over $90 \%$ Percoll) and centrifugation at $1200 \mathrm{rpm}$ for $25 \mathrm{~min}$. The pellet was washed twice and finally resuspended in $1 \mathrm{ml}$ of Tyrode's albumin lactate pyruvate (TALP-SP) (containing $2 \mathrm{mM}$ sodium pyruvate, $50 \mu \mathrm{g} / \mathrm{ml}$ gentamycin and $3 \mathrm{mg} / \mathrm{ml}$ BSA Fraction V). Approximately, $1 \times 10^{6}$ motile sperms $/ \mathrm{ml}$ were added to the fertilization drop and incubated with $25 \mathrm{COCs}$ for $24 \mathrm{~h}$ at $39^{\circ} \mathrm{C}$ in $5 \% \mathrm{CO}_{2}$ in air atmosphere. Fertilization was carried out in TALP medium supplemented with $2 \mathrm{mM}$ sodium pyruvate, $50 \mu \mathrm{g} / \mathrm{ml}$ gentamycin, $0.01 \mathrm{mg} / \mathrm{ml}$ heparin sodium salt, and $6 \mathrm{mg} / \mathrm{ml}$ of BSA fraction V (essentially fatty acid free). After $24 \mathrm{~h}$ of IVF, the presumptive zygotes were mechanically denuded by 3 min vortexing in TCM-Hepes $+0.3 \mathrm{mg} / \mathrm{ml}$ of hyaluronidase and washed tree times before culture. The embryos were then split in two groups: 1) Zona-free embryos (IVF-ZF) and 2) Zona-included embryos (IVF-ZI). For IVF-ZF, the zona pellucida was removed by pronase treatment $(2 \mathrm{mg} / \mathrm{ml}$ during $5 \mathrm{~min}$ ). Embryos were cultured for 7 days in synthetic oviduct fluid (SOFaci) supplemented with $0.37 \mathrm{mM}$ trisodium citrate, $2.77 \mathrm{mM}$ myo-inositol, essential and non-essential amino acids (final concentration $1 \times$ ), gentamycin $(50 \mu \mathrm{g} / \mathrm{ml}), 3 \mathrm{mg} / \mathrm{ml}$ essentially fatty acid free bovine serum albumin (BSA), 2\% FBS and $10 \mathrm{ng} / \mathrm{ml} \mathrm{EGF}$ in a balanced gas atmosphere consisting of $5 \% \mathrm{CO}_{2}, 5.5 \% \mathrm{O}_{2}$ and $89.5 \% \mathrm{~N}_{2}, 100 \%$ humidity at $39^{\circ} \mathrm{C}$. IVF-ZF embryos were cultured individually in well of the well system (WOW) (Vajta et al 2000) of a 4-well dish (Nalge Nunc, Damstead, Germany).

For the production of parthenogenetic embryos, matured oocytes were denuded and then activated using $7 \%$ ethanol in TCM199-HEPES for $5 \mathrm{~min}$, followed by $5 \mathrm{~h}$ 
incubation in TCM199 without HEPES supplemented with cycloheximide $(10 \mu \mathrm{g} / \mathrm{ml})$ and cytochalasin B $(5 \mu \mathrm{g} / \mu \mathrm{l})$ at $39{ }^{\circ} \mathrm{C}$ in a $5 \% \mathrm{CO}_{2}$ in air atmosphere (Rodriguez et al 2008). Parthenogenetic zona-free (P-ZF) and zona-included (P-ZI) embryos were produced and cultured following the same procedures described for IVF embryos.

Additionally, the zona pellucida was removed from a group of matured oocytes before the parthenogenetic activation. Zona-free oocytes were activated and culture using the same protocols and conditions described above. This group was named as ZF-B.

\section{EMBRYO PROCESSING}

Twenty-four hours after culture, the percentage of cleavage was determined. After that, embryos were cultured until day-7 without disturbance. At day-7, embryos were classified according to their stage of development and morphology and stained for cell counting or pooled for gene expression analysis. At least 10 grade I and expanded blastocysts from each group, were fixed in 3\% glutaraldehyde during $72 \mathrm{~h}$ at $4^{\circ} \mathrm{C}$. Fixed embryos were washed in PBS with $1 \%$ PVA and stained with propidium iodide $(10 \mu \mathrm{g} / \mathrm{ml})$ for cell counting under x100 magnification.

\section{GENE EXPRESSION ANALYSIS}

Day-7 zona free and zona-included embryos produced by IVF were pooled in three groups of five embryos each for RNA extraction. Total RNA was isolated using the Absolutely RNA Nanoprep Kit (Stratagene, La Jolla, CA, USA) according to the manufacturer's instructions. Elution was done in $20 \mu \mathrm{l}$ of diethylpyrocarbonate (DEPC)-treated water and the eluted product was stored at $-80^{\circ} \mathrm{C}$ until use. For cDNA conversion, $7 \mu$ l of total RNA was treated with
1U of RNAse-free DNase I (Invitrogen, Carlsbead, CA, USA) in a $10 \mu \mathrm{l}$ reaction for $30 \mathrm{~min}$ at $37^{\circ} \mathrm{C}$. The enzyme was heat-inactivated $\left(65^{\circ} \mathrm{C}\right.$ for $\left.10 \mathrm{~min}\right)$ in the presence of $25 \mathrm{mM}$ EDTA $(1 \mu \mathrm{l})$. Reverse transcription (RT) was performed as described earlier (Rodriguez-Alvarez et al 2010). In brief, the total volume of the DNase I treatment $(11 \mu \mathrm{l})$ was used in a $20 \mu \mathrm{l}$ final reaction containing $30 \mathrm{ng} / \mu \mathrm{l}$ random primers, $10 \mathrm{mM}$ each $\mathrm{dNTP}$, $4 \mu \mathrm{l}$ first strand buffer (5×), $200 \mathrm{U} / \mathrm{ml}$ M-MuLV (Bioline, Darmstadt, Germany) and DEPC-treated water. Cycling parameters were: $25^{\circ} \mathrm{C}$ for $10 \mathrm{~min}, 42^{\circ} \mathrm{C}$ for $60 \mathrm{~min}$ and $70{ }^{\circ} \mathrm{C}$ for $10 \mathrm{~min}$. The produced cDNAs were kept frozen at $-20^{\circ} \mathrm{C}$ until use in PCR experiments.

Six genes related with the apoptotic pathway $(n=3$; BAX, BCL2L1 and CASP3), cell-cell communication (CDH1) and pluripotency (OCT4 and SOX2) were studied by real-time quantitative PCR. In this study, ACTB was used as an internal control, based on our previous experience comparing ACTB versus 18S rRNA as internal standards. Gene expression analysis was performed using the standard curve method. Standard curves for each gene were prepared using PCR products excised and eluted from agarose gels using gel extraction Kit (Omega Biotek, Norcross, GA USA) and quantified by Epoch (Epoch Micro-Volume Spectrophotometer System, BioTek Instruments, Inc, Winooski, VT USA).

Serial dilutions of PCR products were prepared and $2 \mu \mathrm{l}$ were used in duplicates for each point of the standard curve. Samples were also loaded as duplicates for qPCR. The qPCR was performed in $10 \mu \mathrm{l}$ reaction containing $5 \mu \mathrm{l}$ of SensiMixPlus SYBR Kit (Quantace Ltd., Berlin, Germany), $200 \mathrm{nM}$ of each primer and $2 \mu \mathrm{l}$ of cDNA. The composition of primers and PCR conditions for each gene assayed is shown in table 1 . The built-in software calculated the Crossing Point (CP) and the amplification efficiency.

Table 1. Oligonucleotide composition and PCR conditions for the analyzed genes from bovine embryos.

Secuencia de partidores y condiciones de PCR para el análisis de la expresión génica en embriones bovinos.

\begin{tabular}{|c|c|c|c|c|}
\hline Gene Name & Primer Sequences & $\mathrm{T}^{\circ} \mathrm{C}$ annealing & Product length (bp) & Accession $\mathrm{N}^{\circ}$ \\
\hline OCT4 & $\begin{array}{l}\text { F: 5' - GGAGAGCATGTTCCTGCAGTGC 3' } \\
\text { R: 5' - ACACTCGGACCACGTCCTTCTC 3' }\end{array}$ & $58^{\circ} \mathrm{C}$ & 95 & NM-174580 \\
\hline SOX2 & $\begin{array}{l}\text { F: 5' -CGAGTGGAAACTTTTGTCCG 3', } \\
\text { R: 5' -GGTATTTATAATCCGGGTGTT 3' }\end{array}$ & $55^{\circ} \mathrm{C}$ & 101 & NM-001105463 \\
\hline BAX & $\begin{array}{l}\text { F: 5' -AGGGTTTCATCCAGGATCGAGC 3', } \\
\text { R: 5' - TCATCTCCGATGCGCTTCAGAC 3' }\end{array}$ & $58^{\circ} \mathrm{C}$ & 124 & NM-001191220.1 \\
\hline BCL2L1 & $\begin{array}{l}\text { F: 5' - GAAAGCGTAGACAAGGAGATG 3', } \\
\text { R: 5' - CCGTAGAGTTCCACAAAAGTG 3' }\end{array}$ & $58^{\circ} \mathrm{C}$ & 131 & NM-001077486.2 \\
\hline CDH1 & $\begin{array}{l}\text { F: 5' - CTTTGGTGCTGAGAGTTAC 3' } \\
\text { R: 5' - CTTTGAATCGGGTGTCATC 3' }\end{array}$ & $58^{\circ} \mathrm{C}$ & 137 & NM-001002763 \\
\hline CASP3 & $\begin{array}{l}\text { F: 5' - GAAGCAAATCAATGGACTCTGG 3' } \\
\text { R: 5' - GCATCCACGTCTGTACCAG 3' }\end{array}$ & $58^{\circ} \mathrm{C}$ & 141 & NM-001077840 \\
\hline ACTB & $\begin{array}{l}\text { F: 5' - GGCCAACCGTGAGAAGATGACC 3, } \\
\text { R: 5' - GAGGCATACAGGGACAGCACAG 3, }\end{array}$ & $58^{\circ} \mathrm{C}$ & 96 & ВT030480.1 \\
\hline
\end{tabular}




\section{EXPERIMENTAL DESIGN}

In this work two different experiments were carried out in order to test the effect of zona pellucida removal on in vitro produced bovine embryos.

Experiment 1: Effect of the zona pellucida removal on embryo development to blastocyst stage. The developmental potential of zona-free embryos was assessed by comparing the following morphological parameters: 1) rate of first cleavage at $24 \mathrm{~h}$ of culture; 2 ) rate of blastocyst at D-7 of culture and 3) total cell number at blastocyst stage. The comparisons were performed between $\mathrm{ZF}$ and ZI embryos produced by the same method. In a first analysis, removing the zona pellucida after IVF or parthenogenetic activation generated ZF embryos. In a second assay, the same parameters were compared among zona-included and zona-free embryos but in this case, embryos were generated only by parthenogenesis and the zona pellucida was removed before oocyte activation. At least three replicates and 20 embryos were used for each experimental group.

Experiment 2: Effect of the zona pellucida removal after IVF on gene expression at blastocyst stage. In this experiment, the effect of zona pellucida removal was determined by analyzing the gene expression pattern in zona-included and zona-free embryos produced by IVF.

At least three replicates and 20 embryos were used for each experimental group.

\section{STATISTICAL ANALYSIS}

Wilcoxon nonparametric test for two groups was used for comparison of: percentage of cleavage at $24 \mathrm{~h}$ of culture, blastocyst rate and total cell number among $\mathrm{ZF}$ and ZI embryos produced by IVF or parthenogenesis, as well as individual differences in gene expression among $\mathrm{ZF}$ and ZI embryos produced by IVF. In all cases, significant differences were considered if $\mathrm{P}<0.05$. The software used was InfoStat (Buenos Aires, Argentina).

\section{RESULTS}

EXPERIMENT 1: EFFECT OF THE ZONA PELLUCIDA REMOVAL ON EMBRYO DEVELOPMENT TO BLASTOCYST STAGE

In this experiment it was first evaluated the effect of zona pellucida removal on embryo development after in vitro fertilization or parthenogenetic activation. For this, a total of 796 zygotes were produced by IVF, and 406 by parthenogenetic activation of matured oocytes. Embryos were split in two groups (ZI and ZF embryos); 181 and $87 \mathrm{ZF}$ embryos out of the total number were obtained by removing the zona pellucida after IVF or parthenogenesis respectively. The remaining embryos were cultured with zona pellucida (ZI embryos).

In IVF embryos, the rate of cleavage after $24 \mathrm{~h}$ of culture was higher in ZF embryos; however this difference was not statistically significant. On the contrary, the rate of blastocyst and total cell number tended to be higher in ZI embryos but the differences were not statistically different (table 2). The figure for parthenogenetic embryos followed the same general pattern; however the rate of embryos that cleaved at $24 \mathrm{~h}$ was significantly higher in $\mathrm{ZF}$ parthenogenetic embryos but this did not impact upon further development to blastocyst stage (table 2). Representative pictures of ZF and ZI embryos produced by IVF or parthenogesis are shown in figure 1.

Subsequently, it was evaluated the effect of zona pellucida removal before oocyte activation on the outcome of the activation protocol, expressed in cleavage and blastocysts rate. The rationale for this relies on the need for this procedure in some techniques for embryo production such as hand made cloning. To test this, 176 matured oocytes were activated after removing the zona pellucida; the rate of first cleavage, of D-7 blastocysts and total cell number was compared with the data obtained for ZI parthenogenetic embryos (table 3). In this case, no significantly differences were observed for any of the studied parameters.

Table 2. In vitro development and total cell number of embryos produced by in vitro fertilization and parthenogenesis.

Desarrollo in vitro y número total de células en embriones producidos por fecundación in vitro y activación partenogenética.

\begin{tabular}{lccccc}
\hline Embryos produced by & Zona Pellucida & Replicates & Cleaved 24h (\%) & D7 Blastocysts (\%) & N $^{\circ}$ Total cells \pm SD \\
\hline IVF & ZF & 5 & $142(77.2)$ & $69(21.8)$ & $132 \pm 25$ \\
IVF & ZI & 9 & $433(70.1)$ & $142(23.4)$ & $146 \pm 47$ \\
Parthenogenesis & ZF & 3 & $68(78.3)^{\mathrm{a}}$ & $22(25.6)$ & $76 \pm 17$ \\
Parthenogenesis & ZI & 6 & $153(51.3)^{\mathrm{b}}$ & $92(28.8)$ & $82 \pm 20$ \\
\hline
\end{tabular}

ZF, ZI. Zona-free and zona-included embryos respectively. In ZF embryos, the zona pellucida was removed after IVF or parthenogenetic activation. Different superscripts within a column indicate a significant difference. $\mathrm{P}<0.05$. (Comparison was performed between $\mathrm{ZF}$ and $\mathrm{ZI}$ embryos produced by the same method. No comparison was performed between IVF and parthenogenesis).

ZI, ZF. Embriones con y sin zona pelúcida respectivamente. Para los embriones ZF, la zona pelúcida fue removida después de la FIV o activación partenogenética. Letras diferentes dentro de una misma columna significan diferencia significativa con $\mathrm{P}<0,05$. (Comparación solo para el mismo método de producción de embriones). 

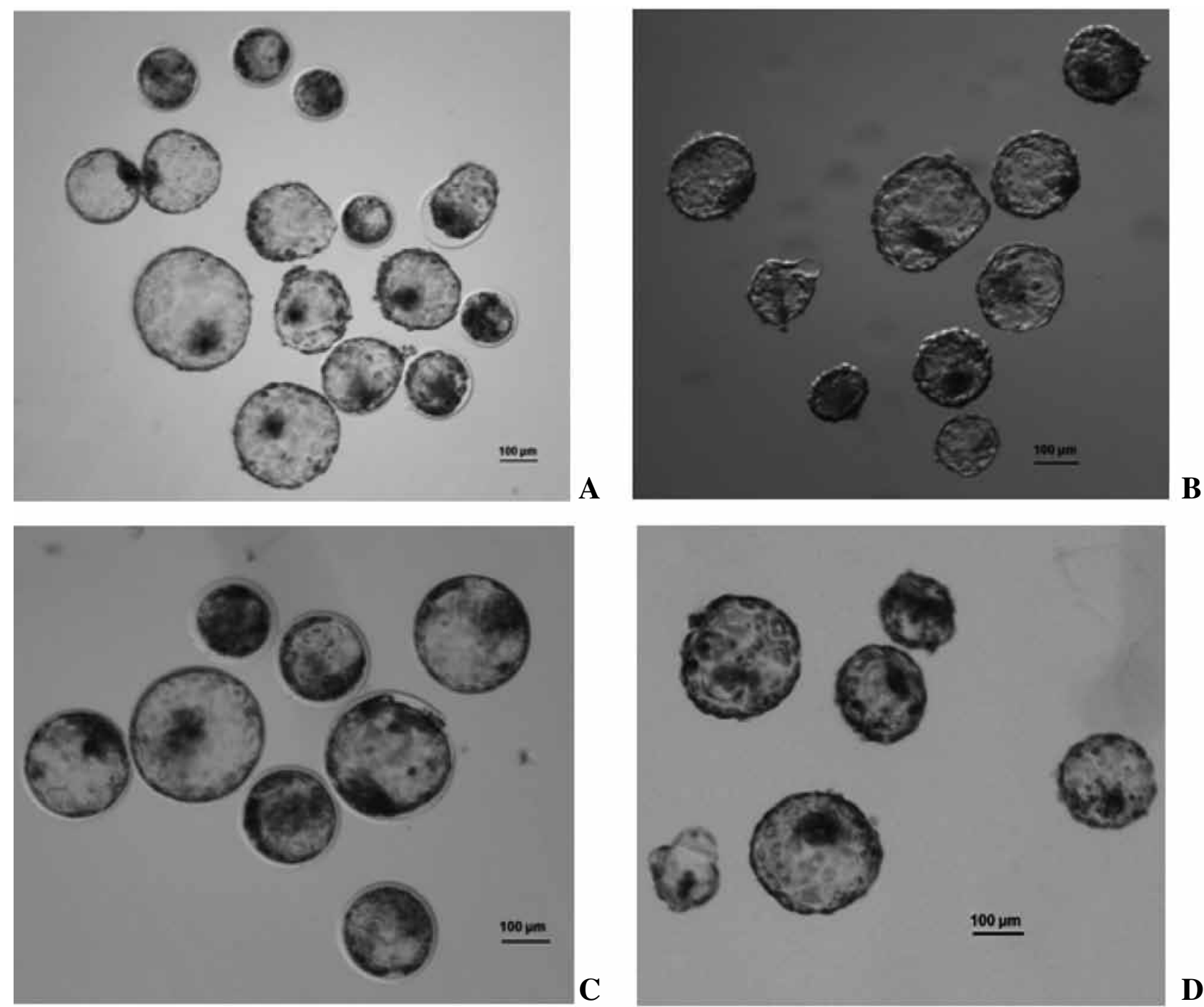

B

Figure 1. Representative microphotographs of embryos produced by IVF or parthenogenesis and cultured with or without zona pellucida. A: In vitro fertilized, zona-included (IVF- ZI), B: IVF, zona-free (IVF-ZF), C-D: Parthenogenetically activated, zona-included (C), or zona-free (D). Scale bars are embedded.

Microfotografía representativa de embriones producidos por fecundación in vitro (FIV) o partenogénesis, cultivados con y sin zona pelúcida. A: Fecundados in vitro y cultivados con zona pelúcida (IVF- ZI), B: FIV cultivados sin zona (IVF-ZF), C-D: Embriones producidos por activación partenogenética y cultivados con zona (C) y sin zona (D). Escala de medida incluida en cada foto.

Table 3. In vitro development and total cell number of embryos produced by parthenogenetic activation of zona-free or zona-included oocytes.

Desarrollo in vitro y número total de células en embriones producidos por activación partenogenética de ovocitos con y sin zona pelúcida.

\begin{tabular}{lccccc}
\hline Embryos produced by & $\begin{array}{c}\text { Zona } \\
\text { Pellucida }\end{array}$ & Replicates & $\begin{array}{c}\text { Cleaved } \\
24 h \\
(\%)\end{array}$ & $\begin{array}{c}\text { D7 } \\
\text { Blastocysts } \\
(\%)\end{array}$ & $\begin{array}{c}\text { Media } \\
N^{\circ} \text { Total } \\
\text { cells } \pm \text { SD }\end{array}$ \\
\hline Parthenogenesis & ZF-B & 5 & $103(60.7)$ & $54(25.5)$ & $79 \pm 11$ \\
Parthenogenesis & ZI & 6 & $153(51.3)$ & $92(28.8)$ & $82 \pm 20$ \\
\hline
\end{tabular}

ZF-B, ZI: Zona-free and zona-included embryos respectively. ZF-B: The zona pellucida was removed before oocyte activation.

ZI, ZF-B: Embriones con y sin zona pelúcida. ZF-B: La zona pelúcida fue removida antes de la activación partenogenética. 
EXPERIMENT 2: EFFECT OF THE ZONA PELLUCIDA REMOVAL AFTER IVF ON GENE EXPRESSION AT BLASTOCYST STAGE

In a second experiment the expression level of genes related with the apoptosis pathway (BAX, BCL2L1 and CASP3), cell-cell communication (CDH1) and pluripotency (OCT4 and SOX2) was evaluated in order to determine the effect of the zona pellucida removal on embryo quality. For this, IVF embryos were used as biological model and removing the zona pellucida after in vitro fertilization produced ZF embryos. Out of the six examinedsd genes, only CASP3 could not be quantified. The remaining genes as well as the housekeeping gene ACTB, used as normalizer, were successfully amplified within the linear range of the detection.

There was a tendency to induce the pro-apoptotic mechanisms in ZF embryos reflected by a higher level of the expression BAX and the lower level of BCL2L1 in those embryos. However there was not a significant difference in the resulting BAX/BCL2L1 ratio (figure 2). Similarly, not significant differences were obtained in the expression level of CDH1, OCT4 and SOX2 between ZF and ZI embryos (figure 3).
Ratio BAX/BCL2L1

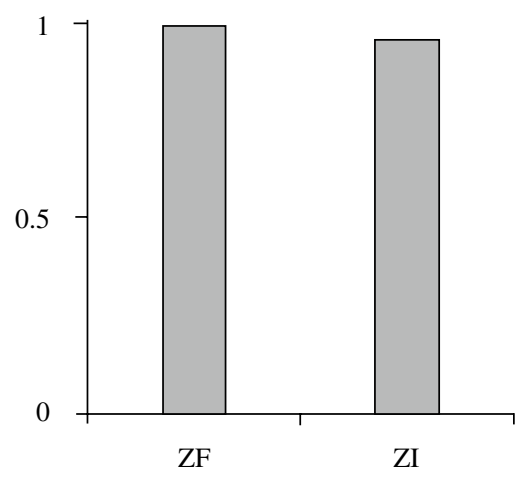

Figure 2. Expression ratio of BAX/BCL2L1 genes in D-7 bovine blastocysts produced by IVF. ZI and ZF: embryos cultured with or without zona pellucida respectively. Ratio was calculated from quantitative PCR data.

Razón de la expresión de los genes BAX/BCL2L1 en blastocistos bovinos D-7 producidos por FIV. ZI y ZF: embriones cultivados con y sin zona pelúcida respectivamente. La razón fue calculada a partir de los datos de PCR cuantitativo.
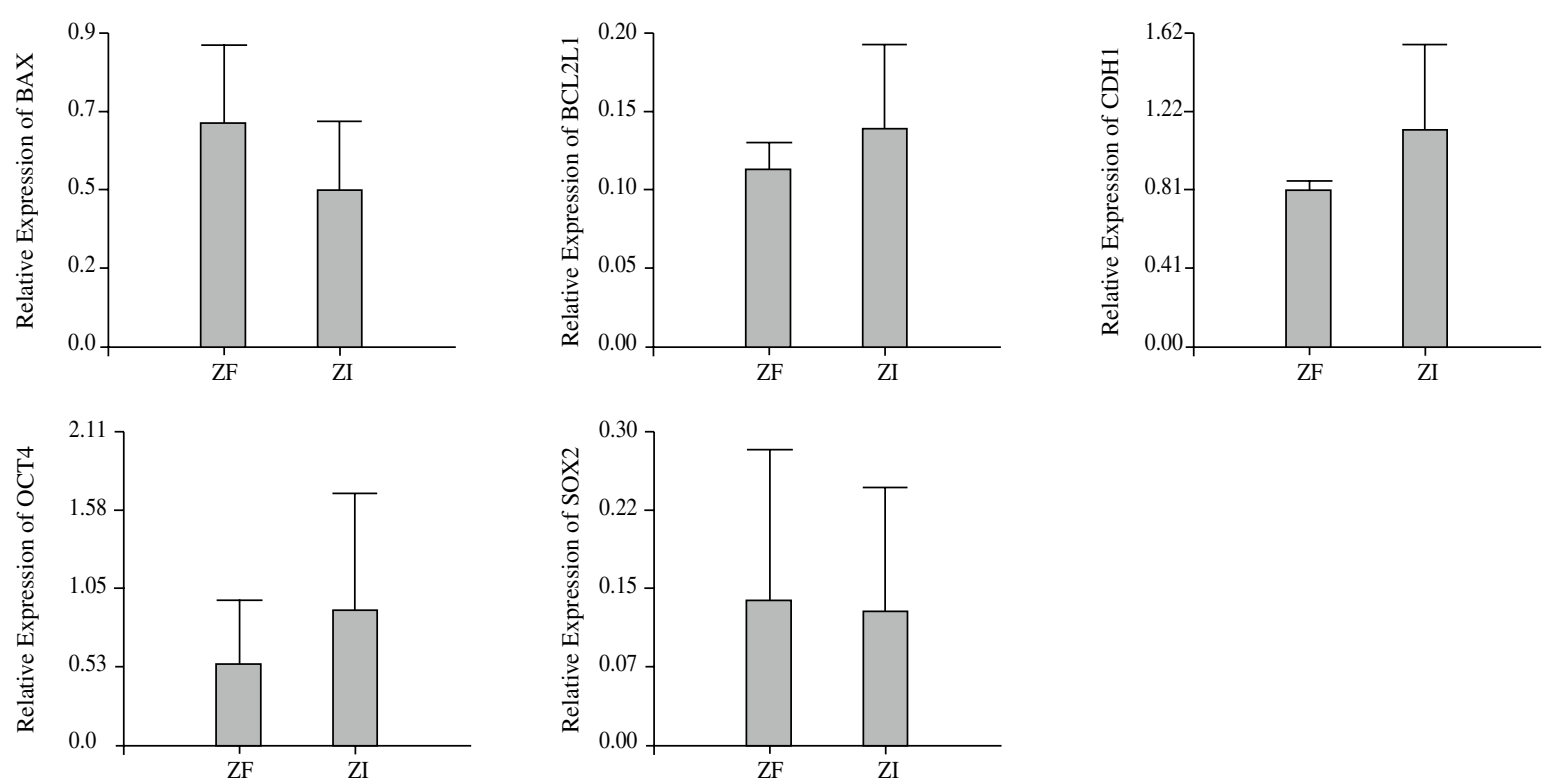

Figure 3. Relative gene expression levels by Q-PCR in embryos produced by IVF and cultured with or without zona pellucida. ZF: Zona-free embryos. ZI: Zona-included embryos. The expression level of each gene was normalized to the expression of ACTB measured in the same RNA preparation.

Expresión relativa a B-actina de los genes BAX, BCL2L1, CDH1, OCT4 y SOX2 en blastocistos bovinos producidos por FIV y cultivados con (ZI) y sin zona pelúcida (ZF).

\section{DISCUSSION}

It is well known that, in vivo, the zona pellucida plays important functions during fertilization and early development in mammalian embryos. However, the presence of this membrane does not seem to be essential for normal development when the embryos are produced in vitro. This study evaluated the effect of the absence of the zona pellucida during the pre-implantation bovine embryo development. The first cleavage, the development potential to blastocyst stage and the total cell number at Day-7 were compared among zona-free and zona-included embryos produced by parthenogenesis and IVF as well. In humans, transfer of zona-free embryos is an effective method to increase implantation of poor-quality blastocyst. However, it has been shown that prolonged exposure of the blastocyst to 
pronase might damage the trophoectoderm and the inner cell mass structures due to a collapse of the blastocele cavity (Fong et al 2001).

In this study, zona-free embryos were produced by pronase digestion of the zona pellucida after in vitro fertilization or parthenogenetic activation and then cultured individually in a well of well system until blastocyst stage. The zona pellucida was digested in $98 \%$ of the embryos and no damage of the membrane was observed in any of the zona-free embryos (data not shown). Removal of the zona pellucida in these experiments did not affect any of the parameters evaluated to assess embryo development capability (rate of the first cell cleavage, blastocyst rate and total cell number). The fact that the blastocysts rate and total cell number did not differ between zona-free and zona-included embryos, suggests that the system used for embryo culture guarantees the normal contact and compaction of the blastomeres, maintaining the signal transduction to allow cell determination and differentiation during early embryo development. Additionally, in previous studies, healthy calves have been obtained by transferring zona-free blastocysts produced by HMC, a cloning method in which cloned embryos are produced and culture without zona pellucida (Vajta et al 2001, Ribeiro et al 2009, Rodriguez-Alvarez et al 2010).

Moreover, the blastocyst rate was significantly higher in zona-free parthenogenetic embryos compared with its counterpart. This result apparently indicates that the absence of zona pellucida facilitates the access of the oocyte to factors required for chemical activation and first cell division after parthenogenesis. Based on that, and also because using HMC to produce cloned embryos requires removal of the zona pellucida for oocyte enucleation, it was compared the development potential of zona-free embryos produced by removing the zona pellucida before and after parthenogenesis. In this case, the activation mechanisms and the first cell division were not improved. No significant differences were observed in any of the studied parameters between the two groups of embryos. This is indicative that the absence of the zona pellucida does not impair embryonic development, even when the zona pellucida is removed before oocyte activation.

In the second experiment, it was evaluated the effect of zona pellucida removal after in vitro fertilization on the expression level of genes related with the apoptosis pathway (BAX, BCL2L1 and CASP3), cell-cell communication (CDH1) and pluripotency (OCT4 and SOX2). Potentially the absence of zona pellucida during embryo culture could provoke a lack of contact between the blastomeres, thus it might be expected an increase of cell death by apoptosis and consequently an induction of apoptotic mechanisms. Apoptosis occurs during early embryo development stages both in in vitro and in vivo produced embryos; however, the incidence of cell death by apoptosis might increase as a consequence of the procedures for in vitro embryo production (Gómez et al 2009).
From the three genes involved in the apoptotic pathway that were studied in this work, only CASP3 could not be quantified, in a quantitative assay using $1 / 5^{\text {th }}$ of a blastocyst as input for cDNA conversion; conversely both BAX and BCL2L1 were detected and quantified in zona-free and zona-included embryos as well. Both BAX and BCL2L1 are members of the BCL2 superfamily of proteins that regulates the permeability of the mitochondrial membrane in the intrinsic apoptotic pathway. The balance between anti, and pro-apoptotic proteins determines whether the cell undergoes apoptosis or not (Duan et al 2005). The antiapoptotic proteins BCL2 and BCL2L1 inhibit apoptosis by forming heterodimers with pro-apoptotic proteins like BAX. This process prevents mitochondrial pore formation mediated by homodimeres of BAX or other pro apoptotic proteins like BAK and BOK for instances (Adams and Cory 1998).

In this study, it was found a marginal increase in the expression level of BAX and a decrease in the expression of BCL2L1 in zona-free embryos; still, these differences were not statistically significant. Furthermore, BAX/BCL2L1 balance was not significant higher in zona-free embryos. This indicates that induction of cell death by apoptosis as a consequence of the absence of the zona pellucida in zona-free embryos did not happen.

Similarly to the above described results, no significant differences were obtained in the expression level of CDH1, OCT4 and SOX2 among zona-free and zona-included IVF-derived embryos. In previous studies it has been demonstrated that a change in the expression pattern of pluripotency markers such as OCT4 is related with the regulation of the expression and the balance of pro and anti apoptotic proteins. For instance, an increase in the BAX/ BCL2 ratio is consistent with the reduction of the OCT4 expression in bovine blastocysts produced by parthenogenesis (Gómez et al 2009) while pig parthenotes treated with melatonin showed a decrease of BAX expression and increased of BCL2L1 and OCT4 expression (Choi et al 2008). In the experiments presented here, there was no drift in the expression of OCT4 as a function of the apoptotic activity as judged by the expression of the studied genes. This might be indicative of a species-specific difference in the balance between pluripotency and apoptosis in bovine at the blastocysts stage, which can be related with differences in implantation and trophoblast function in ruminants, where embryo elongates significantly before implantation.

Other studies reported that intercellular structures are altered in in vitro produced embryos, most likely due to a reduction of the expression of genes responsible for compaction and cell-cell adhesion such as CX43 and CDH1 respectively (Wrenzycki et al 1996, Rizos et al 2003). CX43 have been linked to embryo quality, while CDH1 is more involved in blastocyst formation (Rizos et al 2003, Lonergan et al 2003). In this study, the CDH1 expression and consequently the normal blastocyst formation is not 
affected by the absence of zona pellucida during culture of IVF-derived embryos.

It is concluded that removal of zona pellucida during early embryonic stages does not affect neither the developmental potential to blastocyst nor the quality of bovine embryos produced in vitro. Furthermore, no changes were found in gene expression pattern among zona-free and zona-included embryos, at least for the subset of genes studied here. We confirm that culture of zona-free embryos might become a feasible alternative to conventional approach in assisted reproduction, in order to decrease the low implantation rate observed as a consequence of hatching difficulties. We also confirm that the absence of zona pellucida in embryos generated by HMC does not increase gene expression anomalies commonly observed in cloned embryos.

\section{RESUMEN}

Durante el desarrollo embrionario temprano, la zona pelúcida actúa como barrera contra la polispermia y además garantiza la comunicación entre blastómeras y la compactación de estas. Sin embargo, el desarrollo de nuevas tecnologías reproductivas como "hand made cloning" demandan la eliminación de esta membrana. En este estudio nos propusimos determinar el efecto de la remoción de la zona pelúcida sobre el desarrollo in vitro y la calidad de embriones bovinos producidos por FIV o activación partenogenética. La capacidad de desarrollo se evaluó teniendo en cuenta el porcentaje de la primera división celular, porcentaje de blastocistos y número total de células. La comparación se realizó entre embriones con y sin zona pelúcida, a estos últimos la zona le fue removida después de la fecundación o de la activación partenogenética. Adicionalmente se evaluó el efecto de la remoción de la zona, antes de la activación partenogenética, sobre la capacidad de desarrollo. En un segundo experimento se evaluó el efecto de remover la zona pelúcida sobre los niveles de expresión génica (BAX, BCL2, CASP3, CDH1, OCT4 and SOX2) en embriones producidos por FIV. No se encontraron diferencias significativas en los parámetros incluidos para evaluar el desarrollo embrionario entre embriones con y sin zona pelúcida, producidos por FIV o partenogénesis, en estos últimos eliminando la zona antes de la activación. Sin embargo, en los embriones partenogenéticos en los que se eliminó la zona después de la activación, aumentó significativamente el porcentaje de la primera división comparado con los embriones con zona, sin embargo, esto no tuvo ningún efecto sobre el posterior desarrollo hasta blastocisto. De igual modo, no se encontraron diferencias significativas en los niveles de expresión génica entre embriones con y sin zona pelúcida producidos por FIV, para los genes estudiados. De esta forma se concluye que la ausencia de zona pelúcida no afecta el desarrollo temprano de embriones bovinos cuando se utiliza un sistema de cultivo que garantice el correcto contacto y compactación celular.

\section{ACKNOWLEDGEMENTS}

The authors would like to thank Carnes Ñuble, Chillán, for providing the ovaries and Dr. Patricio Bustamante for his invaluable support.

\section{REFERENCES}

Adams JM, S Cory. 1998. The Bcl-2 protein family: arbiters of cell survival. Science 281, 1322-1326.

Austin CR, AWH Braden.1956. Early reactions of the rodent egg to spermatozoon penetration. J Exp Biol 33, 358-366.
Bedford J. 2008. Puzzles of mammalian fertilization and beyond. Int $J$ Dev Biol 52,415-426.

Bhojwani S, G Vajta, H Callesen, K Roschlau, A Kuwer, F Becker, H Alm, H Torner, W Kanitz, R Poehland. 2005. Developmental competence of HMC (TM) derived bovine cloned embryos obtained from somatic cell nuclear transfer of adult fibroblasts and granulosa cells. J Reprod Dev 51, 465-475.

Bronson RA, A McLaren. 1970. Transfer to the mouse oviduct of eggs with and without the zona pellucida. J Reprod Fertil 22, 129-137.

Choi J, SM Park, E Lee, JH Kim, YI Jeong, JY Lee, SW Park, HS Kim, MS Hossein, YW Jeong, S Kim, SH Hyun, WS Hwang. 2008. Anti-apoptotic effect of melatonin on preimplantation development of porcine parthenogenetic embryos. Mol Reprod Dev 75, 1127-1135.

Cohen J, C Elsner, H Kort, J Massey, MP Mayer, K Wiemer. 1990. Impairment of the hatching process following IVF in the human and improvement of implantation by assisted hatching using micromanipulation. Hum Reprod 5, 7-13.

Cohen J, M Alikani, J Trowbridge, Z Rosenwaks. 1992. Implantation enhancement by selective assisted hatching using zona drilling of human embryos with poor prognosis. Hum Reprod 7, 685-688.

Duan XX, JS Ou, Y Li, JJ Su, C Ou, C Yang, HF Yue, KC Ban. 2005. Dynamic expression of apoptosis-related genes during development of laboratory hepatocellular carcinoma and its relation to apoptosis. World J Gastroenterol 11, 4740-4744.

Edwards RG, HK Beard. 1997. Oocyte polarity and cell determination in early mammalian embryos. Mol Hum Reprod 3, 863-905.

Fong CY, A Bongso, SC Nq, C Anandakumar, A Trounson, S Ratnam. 1997. Ongoing normal pregnancy after transfer of zona free blastocysts: implications for embryo transfer. Hum Reprod 12, 557-560.

Fong CY, A Bongso, SC Ng. 1998. Blastocyst pregnancy after enzymatic treatment of the zona pellucida: improving in vitro fertilization and understanding implantation. Hum Reprod 13, 2926-2932.

Fong CY, A Bongso, H Sathananthan, J Ho, S Ng. 2001. Ultrastructural observations of enzymatically treated human blastocysts: zona free blastocyst transfer and rescue of blastocysts with hatching difficulties. Hum Reprod 16, 540-546.

Gómez E, JN Caamaño, P Bermejo-Alvarez, C Díez, M Muñoz, D Martín, S Carrocera, A Gutiérrez-Adán. 2009. Gene expression in early expanded parthenogenetic and in vitro fertilized bovine blastocysts. J Reprod Dev 55, 607-614.

Jelinkova L, J Pavelkova, E Strehler, W Paulus, J Ziyny, K Sterzik. 2003. Improved implantation rate after hemical removal of the zona pellucida. Fertil Steril 79, 1299-1303.

Lagutina I, G Lazzari, R Duchi, P Turini, I Tessaro, D Brunetti, S Colleoni, G Crotti, C Galli. 2007. Comparative aspects of somatic cell nuclear transfer with conventional and zona-free method in cattle, horse, pig and sheep. Theriogenology 67, 90-98.

Levy RR, H Cordonier, JC Czyba, JF Goerin. 2001. Apoptosis in preimplantation mammalian embryo and genetics. Int $J$ Anat Embryol 106,101-108.

Lonergan P, D Rizos, A Gutierrez-Adán, PM Moreira, B Pintado, J de la Fuente, MP Boland. 2003. Temporal divergence in the pattern of messenger RNA expression in bovine embryos cultured from the zygote to blastocyst stage in vitro or in vivo. Biol Reprod 69, 1424-1431.

Michelmann HW, D Rath, E Töpfer-Petersen, P Schwartz. 2007. Structural and functional events on the porcine zona pellucida during maturation, fertilization and embryonic development: a scanning electron microscopy analysis. Reprod Domest Anim 42, 594-602.

Ribeiro Ede S, RP Gerger, LU Ohlweiler, I Ortigari Jr, JC Mezzalira, F Forell, LR Bertolini, JL Rodrigues, CE Ambrósio, MA Miglino, A Mezzalira, M Bertolini. 2009. Developmental potential of bovine hand-made clone embryos reconstructed by aggregation or fusion with distinct cytoplasmic volumes. Cloning Stem Cells 11, 377-386. 
Ritchie WA, JE Taylor, JO Gardner. 2005. Live lambs born from zonapellucida deduced embryos. Cloning Stem Cells 7, 178-182.

Rizos D, A Gutiérrez-Adán, S Pérez-Garnelo, J de la Fuente, MP Boland, P Lonergan. 2003. Bovine embryo culture in the presence or absence of serum: implications for blastocyst development, cryotolerance, and messenger RNA expression. Biol Reprod 68, 236-243.

Rodríguez L, FI Navarrete, H Tovar, JF Cox, FO Castro. 2008. High developmental potential in vitro and in vivo of cattle embryos cloned without micromanipulators. J Assist Reprod Genet 25,13-16.

Rodríguez-Alvarez L, J Cox, H Tovar, R Einspanier, FO Castro. 2010. Changes in the expression of pluripotency-associated genes during preimplantation and peri-implantation stages in bovine cloned and in vitro produced embryos. Zygote 18, 269-279.

Stanger JD, K Stevenson, A Lakmaker, R Woolcott. 2001. Pregnancy following fertilization of zona-free, coronal cell intact human ova. Hum Reprod 16, 164-167.

Sun QY. 2003. Cellular and molecular mechanisms leading to cortical reaction and polyspermy block in mammalian eggs. Microsc Res Tech 61, 342-348.

Suzuki H, M Togashi, J Adachi, Y Toyoda. 1995. Developmental ability of zona-free mouse embryos is influenced by cell association at the 4-cell stage. Biol Reprod 53, 78-83.
Urman B, B Balaban, C Alatas, S Aksoy, A Mumcu, A Isiklar. 2002. Zona-intact versus zona-free blastocyst transfer: a prospective, randomized study. Fertil Steril 78, 392-396.

Vajta G, TT Peura, P Holm, A Páldi, T Greve, A Trounson, H Callesen. 2000. A new method for the culture of zona-included or on-free embryos: the Well of the Well (WOW) system. Mol Reprod Dev $55,256-264$.

Vajta G, IM Lewis, P Hyttel, G Thouas, A Trounson. 2001. Somatic cell cloning without micromanipulators. Cloning 3, 89-95.

Vajta G, Korösi T, Y Du, K Nakata, S Ieda, M Kuwayama, Z Nagy. 2008. The well-of-the-well system: an efficient approach to improve embryo development. Reprod BioMed Online 17, 73-81.

Wolf E, GJ Arnold, S Bauersachs, HM Beier, H Blum, R Einspanier, T Fröhlich, A Herrler, S Hiendleder, S Kölle, K Prelle, HD Reichenbach, M Stojkovic, H Wenigerkind, F Sinowatz. 2003. Embryo-maternal communication in bovine - strategies for deciphering a complex cross-talk. Reprod Domest Anim 38, 276-289.

Wrenzycki C, D Herrmann, JW Carnwath, H Niemann. 1996. Expression of the gap junction gene connexin 43 (Cx43) in preimplantation bovine embryos derived in vitro or in vivo. J Reprod Fertil 108, 17-24.

Wassarman PM, ES Litscher. 2008. Mammalian fertilization: the egg's multifunctional zona pellucida. Int J Dev Biol 52, 665-676. 